\title{
List of contributors
}

Andrew Asibong is a Lecturer in French at Birkbeck College, University of London.

Bridget Birchall is a doctoral candidate in French film studies at the University of Exeter.

Lisa Downing is Professor of French Discourses of Sexuality at the University of Exeter.

Peter Evans is Professor of Hispanic Studies and Film Studies at Queen Mary, University of London.

Fiona Handyside is a Lecturer in European Film at the University of Exeter.

Sue Harris is Reader in French Cinema Studies at Queen Mary, University of London.

Cristina Johnston is a Lecturer in French at the University of Stirling.

Bill Marshall is Professor of Modern French Studies at the University of Glasgow.

Pauline Small is a Senior Lecturer in Film at Queen Mary, University of London.

Susan Weiner is a Teacher and Fellowship Adviser at the University of the Pacific, Stockton, California. 
